\title{
Biosensors. A quarter of a century of R\&D experience
}

\author{
A. P. Soldatkin, S. V. Dzyadevych, Y. I. Korpan, T. A. Sergeyeva, V. N. Arkhypova, \\ O. A. Biloivan, O. O. Soldatkin, L. V. Shkotova, O. A. Zinchenko, V. M. Peshkova, \\ O. Y. Saiapina, S. V. Marchenko, A. V. El'skaya
}

Institute of Molecular Biology and Genetics, NAS of Ukraine

150, Akademika Zabolotnogo Str., Kyiv, Ukraine, 03680

a_soldatkin@yahoo.com

\begin{abstract}
The paper is a review of the researches of Biomolecular Electronics Laboratory concerning the development of biosensors based on electrochemical transducers (amperometric and conductometric electrodes, potentiometric pH-sensitive field effect transistors) and different biorecognition molecules (enzymes, cells, antibodies), biomimics (molecularly imprinted polymers), as sensitive elements for direct analysis of substrates or inhibitory analysis of toxicants. Highly specific, sensitive, simple, fast and cheap detection of different substances renders them as promising tools for needs of health care, environmental control, biotechnology, agriculture and food industries. Diverse biosensor formats for direct determination of different analytes and inhibitory enzyme analysis of a number of toxins have been designed and developed. Improvement of their analytical characteristics may be achieved by using differential mode of measurement, negatively or positively charged additional semipermeable membranes, nanomaterials of different origin, genetically modified enzymes. These approaches have been aimed at increasing the sensitivity, selectivity and stability of the biosensors and extending their dynamic ranges. During the last 25 years more than 50 laboratory prototypes of biosensor systems based on mono-and multibiosensors for direct determination of a variety of metabolites and inhibitory analysis of different toxic substances were created. Some of them were tested in real samples analysis. The advantages and disadvantages of the biosensors developed are discussed. The possibility of their practical application is considered.
\end{abstract}

Keywords: electrochemical biosensor, immobilized enzyme, substrate, inhibitor, multibiosensor.

Introduction. The last decades have shown unprecedented interest in the development of analytical devices for the detection, quantification, and monitoring of different biological and chemical compounds. The dynamic field of biosensors is covered by the extensive number of reviews [1-5].

As compared with existing standard methods of substrate determination, electrochemical biosensor methods of analysis have a number of advantages: they provide easy, fast, accurate, highly sensitive, spesific, and cheap procedure of measurement. Besides, real-time measurements are possible, while only minimal probe pretreatment is necessary. A biosensor is a self-contained device consisting of two functional parts. A bioselective element

(C) Institute of Molecular Biology and Genetics, NAS of Ukraine, 2013 is in direct contact with a physical transducer, which transforms the information from biorecognition domain into an electrical or optical signal. The amplitude of such signal depends on the concentration of the analysed compound (analyte) in the sample. Biologically active materials used for the construction of biosensor systems can be divided into two main groups: catalytic (enzymes, cells, tissues, biomimics) and noncatalytic, or affinity (antibodies, receptors, nucleic acids, biomimics). Electrochemical (amperometric, potentiometric, conductometric or impedimetric), optical, calorimetric, and acoustic transducers are currently used in measuring systems. The main endevours in the biosensor development are focused on the exploration of various combinations of biological components (or their synthetic mimics) with different transducers. 
Table 1

Analytical characteristics of developed ENFET biosensors

\begin{tabular}{|c|c|c|c|c|c|c|}
\hline \multirow{2}{*}{ Substrate (enzyme) } & \multirow{2}{*}{ Dynamic range, $\mathrm{M}$} & \multirow{2}{*}{ Operational mode } & \multirow{2}{*}{$\begin{array}{c}\text { Time of } \\
\text { analysis, min }\end{array}$} & \multicolumn{2}{|c|}{ Stability } & \multirow{2}{*}{ References } \\
\hline & & & & Operational, h & Storage, day & \\
\hline \multirow{2}{*}{ Glucose ( Glucose Oxidase) } & \multirow{2}{*}{$10^{-4}-3 \cdot 10^{-3}$} & Kinetic & $0.1-0.2$ & \multirow{2}{*}{$>20$} & \multirow{2}{*}{90} & \multirow{2}{*}[2,6,7]{} \\
\hline & & Steady-state & $1-2$ & & & \\
\hline \multirow{2}{*}{ Urea (Urease) } & \multirow{2}{*}{$10^{-4}-5 \cdot 10^{-3}$} & Kinetic & $0.1-0.2$ & \multirow{2}{*}{$>20$} & \multirow{2}{*}{90} & \multirow{2}{*}[2,8]{} \\
\hline & & Steady-state & $1-3$ & & & \\
\hline \multirow{2}{*}{$\begin{array}{l}\text { Acetylcholine chloride (Acetylcholine } \\
\text { Esterase) }\end{array}$} & \multirow{2}{*}{$10^{-5}-5 \cdot 10^{-3}$} & Kinetic & $0.1-0.2$ & \multirow{2}{*}{$>30$} & \multirow{2}{*}{90} & \multirow{2}{*}[9,10]{} \\
\hline & & Steady-state & $1-3$ & & & \\
\hline \multirow{2}{*}{$\begin{array}{l}\text { Butyrylcholine chloride (Butyrylcholine } \\
\text { Esterase) }\end{array}$} & \multirow{2}{*}{$10^{-4}-10^{-2}$} & Kinetic & $0.1-0.2$ & \multirow{2}{*}{$>30$} & \multirow{2}{*}{90} & \multirow{2}{*}[9,10]{} \\
\hline & & Steady-state & $1-3$ & & & \\
\hline Penicillin (Penicillinase) & $10^{-4}-1.5 \cdot 10^{-2}$ & Steady-state & $1-2$ & $>20$ & 90 & [11] \\
\hline Formaldehyde (Alcohol Oxidase) & $5 \cdot 10^{-3}-2 \cdot 10^{-1}$ & Steady-state & $1-3$ & $>20$ & 30 & [12] \\
\hline Creatinine (Creatinine Deiminase) & $1 \cdot 10^{-5}-5 \cdot 10^{-3}$ & Steady-state & $1-2$ & $>20$ & 180 & {$[13,14]$} \\
\hline 4-Chlorophenol (Tyrosinase) & $2 \cdot 10^{-4}-8 \cdot 10^{-3}$ & Steady-state & $2-4$ & $>150$ & 15 & {$[15,16]$} \\
\hline $\begin{array}{l}\text { Protein substrates (Trypsin, Pronase E, } \\
\text { Trypsin with Carboxypeptidase B) }\end{array}$ & $1-60 \mu \mathrm{g} / \mathrm{ml}$ & Steady-state & $5-7$ & $>10$ & 20 & {$[17,18]$} \\
\hline $\begin{array}{l}\text { Multi detection: specific proteinase activity } \\
\text { determination Trypsin-Chemotrypsin } \\
\text { (proteinase- } \alpha_{2} \mathrm{M} \text { molecule complexes) }\end{array}$ & $0.1-20 \mathrm{U} / \mathrm{ml}$ & Kinetic & $5-7$ & $>15$ & 30 & [19] \\
\hline
\end{tabular}

In this paper our achievements in the development of electrochemical mono- and multibiosensors are reviewed. The laboratory prototypes of such biosensors were created and used in analysis of real samples for future application in medicine, environmental monitoring and food quality control.

Biosensors based on enzyme field effect transistors. The theory, technology and instrumentation for ionselective field-effect transistors (ISFETs) were thoroughly reviewed in [5]. In $\mathrm{pH}$-sensitive field-effect transistors (pH-FETs) an electrical signal depends on surface potential of transistor gate dielectric depending on $\mathrm{pH}$ changes near the transistor's gate.

A differential pair of ISFETs (one - covered with an enzyme-containing membrane, another - a control one with a reference membrane) is usually employed to compensate common interferences such as bulk $\mathrm{pH}$, ion strength, photo- and temperature changes. Enzyme field effect transistors (ENFETs) were obtained by deposition of a thin layer of enzyme-loaded composite over a $\mathrm{pH}$-selective layer of ISFETs. The ENFETs function- ing is based on the measurement of $\mathrm{pH}$ changes, locally occurring inside the bioselective membrane as a result of the enzymatic reaction involving the substrate to be assayed.

ENFETs based on direct analysis. $\mathrm{S} \mathrm{u} \mathrm{b}$ s $\mathrm{tr}$ a t e d i$\mathrm{r}$ e $\mathrm{ct} \mathrm{d}$ e t e c t i o n. We developed ENFETs for direct determination of glucose, urea, acetyl- and butyrylcholine, penicillin, formaldehyde, 4-chlorophenol, creatinine, etc. The $\mathrm{pH}$ changes are a result of enzymatically catalysed conversion of different substrates:

\section{Immobilized enzyme}

Substrate (analyte) $\rightarrow$ product + proton or hydroxylion.

The corresponding enzymes are glucose oxidase (GOD), urease, acetylcholine esterase (AcChE), butyrylcholine esterase $(\mathrm{BuChE})$, penicillinase, alcohol oxidase (AOX), polyphenoloxidase (PPox), creatinine deiminase $(\mathrm{CD})$, etc.

The main analytical characteristics of the developed biosensors are presented in Table 1. 

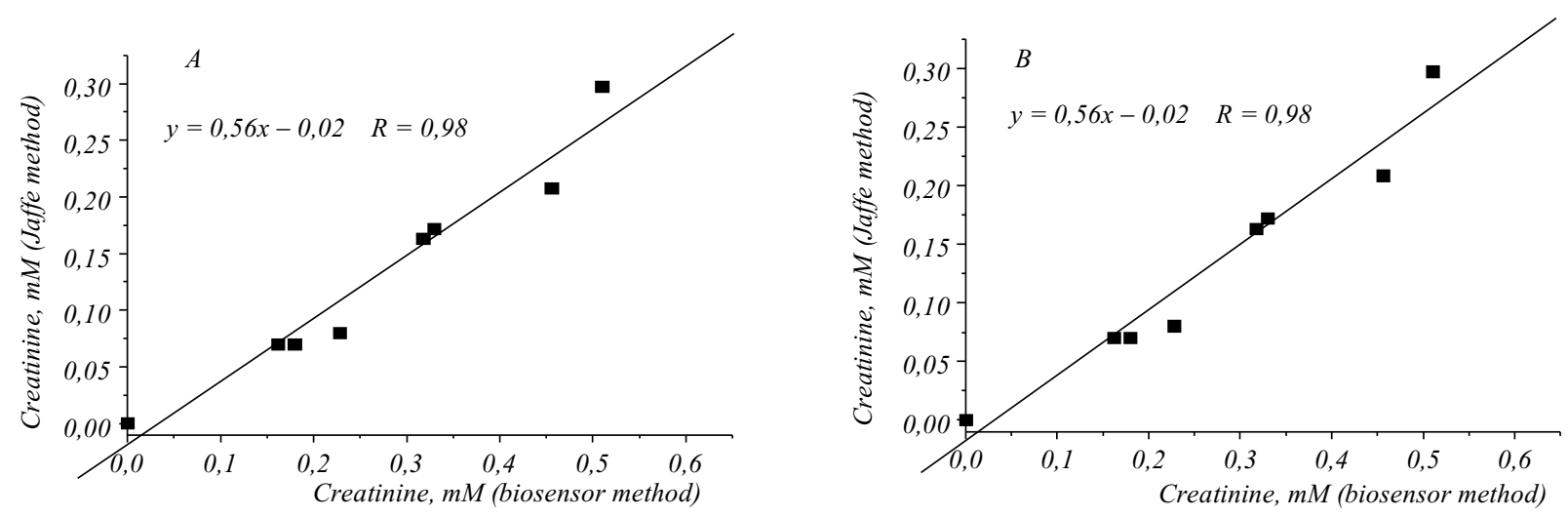

Fig. 1. Correlation of data obtained by biosensor and Jaffe method for creatinine $(A)$, by biosensor and colorimetric enzyme method for urea $(B)$ in dialysate of patient with renal failure

A comprehensive analysis showed that the developed biosensors demonstrated reproducible, stable and fast (1-4 min) responses to the substrates to be measured [6-19]. Unfortunately, application of ENFETs can be restricted because of the dramatic decrease in the sensor response at increasing buffer capacity and ionic strength, $\mathrm{pH}$-dependence of the enzyme kinetics, co-substrate limitation of enzymatic reaction rate (the glucose sensor).

Improvement of ENFETs analytical cha$\mathrm{r}$ a c t e r i s t i c s. The investigation of glucose and urea biosensors showed that main analytical characteristics of ENFETs can be improved by using charged permselective additional membranes [20-24].

A narrow dynamic range of urea biosensors is a disadvantage which does not allow their appplication for measurements in whole human blood (where urea normal concentration is $6-8 \mathrm{mM}$ but much higher in pathology) and, thus, previous sample dilution is required [23]. The dynamic range can be shifted toward higher concentrations by adding sodium tetraborate, a competitive inhibitor of urease [25]. Another way to overcome the problem is modulation of urease affinity as a biorecognition element. Noteworthy is a trend of the last few years to use genetically modified enzymes for the improvement of biosensor characteristics. Thus, we used a new enzyme preparation - recombinant urease from $E s$ cherichia coli with an active site, genetically modified so that urease affinity toward the specific substrate decreased. According to the information of the enzyme preparation producer, it has high, about $200 \mathrm{mM}, K_{\mathrm{m}}$. The improved biosensor had quite broad, $1-80 \mathrm{mM}$, dy- namic range [26], covering urea concentrations in blood and dialysate samples for both normal patients and those with renal dysfunction. Moreover this biosensor demonstrated high reproducibility and storage stability. So, the developed biosensor has working characteristics fitting the medical requirements as for direct urea measurement in blood and dialysis samples.

Determination of creatinine and urea c o n c e n trations. Determination of creatinine and urea, the main compounds of human nitrogen metabolism, is important for diagnostics of pathological states of kidneys and assessment of the hemodialysis effectiveness. For this purpose we developed new enzyme potentiometric monobiosensors and designed their laboratory prototypes. As bioselective elements served immobilized enzymes - creatynindeiminase of microbial origin, urease from soybeans and recombinant urease from E. coli [26].

The biosensors were characterized by short time of analysis (1-2 $\mathrm{min})$, high selectivity, reproducibility (standard deviation did not exceed $5 \%$ ) and storage stability (30-40 days). They were successfully tested in samples of blood serum and dialysate of patients with renal failure $[27,28]$. The measured values of creatinine and urea concentrations in dialysate were compared with the results of traditional methods, a high level of data correlation $(R=0.98)$ being observed in both cases (Fig. 1).

ENFETs based on inhibitory analysis. For determination of different toxic compounds we developed ENFET biosensors based on enzyme inhibition $[2,9,10,30$ 
Table 2

Analytical characteristics of ENFET biosensors based on inhibitory analysis

\begin{tabular}{|c|c|c|c|c|c|c|}
\hline \multirow{2}{*}{ Toxic components } & \multirow{2}{*}{ Enzyme } & \multirow{2}{*}{ Dynamic range, $\mathrm{M}$} & \multirow{2}{*}{$\begin{array}{c}\text { Time of } \\
\text { analysis, min }\end{array}$} & \multicolumn{2}{|c|}{ Stability } & \multirow{2}{*}{ References } \\
\hline & & & & Operational, $\mathrm{h}$ & Storage, day & \\
\hline Heavy metal ions & Urease & $10^{-6}-5 \cdot 10^{-3}$ & 20 & $>10$ & 30 & {$[2,29]$} \\
\hline Diisopropyl fluorophosphate & $\mathrm{AcChE}$ & $3 \cdot 10^{-11}-5 \cdot 10^{-7}$ & 15 & $>10$ & 30 & {$[2,9,30]$} \\
\hline Diisopropyl fluorophosphate & $\mathrm{BuChE}$ & $5 \cdot 10^{-11}-10^{-7}$ & 15 & $>10$ & 30 & {$[2,9,30]$} \\
\hline Trichlorfon & AcChE & $2 \cdot 10^{-7}-10^{-5}$ & 15 & $>10$ & 30 & {$[2,9,30]$} \\
\hline Trichlorfon & $\mathrm{BuChE}$ & $1 \cdot 10^{-6}-10^{-5}$ & 15 & $>10$ & 30 & {$[2,9,30]$} \\
\hline Paraoxon-ethyl & $\mathrm{AcChE}$ & $10^{-6}-5 \cdot 10^{-5}$ & 15 & $>10$ & 30 & {$[2,9,30]$} \\
\hline Paraoxon-ethyl & $\mathrm{BuChE}$ & $5 \cdot 10^{-7}-5 \cdot 10^{-5}$ & 15 & $>10$ & 30 & {$[2,9,30]$} \\
\hline Paraoxon-methyl & AcChE & $10^{-6}-5 \cdot 10^{-5}$ & 15 & $>10$ & 30 & {$[2,9,30]$} \\
\hline Paraoxon-methyl & $\mathrm{BuChE}$ & $5 \cdot 10^{-6}-5 \cdot 10^{-5}$ & 15 & $>10$ & 30 & {$[2,9,30]$} \\
\hline Parathion-methyl & $\mathrm{AcChE}$ & $5 \cdot 10^{-6}-10^{-4}$ & 15 & $>10$ & 30 & {$[30,31]$} \\
\hline Carbofuran & AcChE & $2 \cdot 10^{-6}-10^{-4}$ & 15 & $>10$ & 30 & {$[30,31]$} \\
\hline Hypochlorite & $\mathrm{AcChE}$ & $10^{-5}-3 \cdot 10^{-4}$ & 15 & Disposable & 30 & [31] \\
\hline$\alpha$-Solanine & BuChE & $5 \cdot 10^{-7}-10^{-4}$ & 5 & $>30$ & 30 & {$[30,32-34]$} \\
\hline$\alpha$-Chaconine & BuChE & $2 \cdot 10^{-7}-10^{-4}$ & 5 & $>30$ & 30 & {$[30,32-34]$} \\
\hline Tomatine & BuChE & $2 \cdot 10^{-7}-10^{-4}$ & 5 & $>30$ & 30 & [35] \\
\hline
\end{tabular}

35]. Their main analytical characteristics are presented in Table 2.

Irreversible inhibition of urease. The immobilised urease can be inactivated by heavy metal ions through their direct interaction with sulfhydryl groups of the enzyme active site $[2,29]$. The assay protocol included measurement of the biosensor response to a fixed urea concentration before and after the biosensor incubation in a solution of heavy metal ions. The detection limits were: $1.0 \cdot 10^{-6} \mathrm{M}$ for $\mathrm{Hg}^{2+}, 2.0 \cdot 10-6 \mathrm{M}$ for $\mathrm{Cu}^{2+}, 5.0 \cdot 10^{-6} \mathrm{M}$ for $\mathrm{Cd}^{2+}, 1.0 \cdot 10^{-5} \mathrm{M}$ for $\mathrm{Co}^{2+}, 2.0 \cdot 10^{-5} \mathrm{M}$ for $\mathrm{Pb}^{2+}$ and $1.0 \cdot 10^{-4} \mathrm{M}$ for $\mathrm{Sr}^{2+}$. Thus, the row of heavy metal ions regarding their toxicity toward urease is: $\mathrm{Hg}^{2+}>\mathrm{Cu}^{2+}>\mathrm{Cd}^{2+}>\mathrm{Co}^{2+}>\mathrm{Pb}^{2+}>\mathrm{Sr}^{2+}$. This inhibition is reversible in the presence of a strong chelating agent EDTA [46] which was used as a scavenging agent for reactivation of the enzyme activity and biosensor multi-use.

Irreversible inhibition of cholineste$r$ a s e s. Determination of organophosphorous and carbamate compounds is based on their ability to inhibit cholinesterases irreversibly via interaction with the serine
- OH group in the enzyme active site. A decrease in cholinesterase activity after its interaction with pesticides can be effectively monitored by ENFET biosensors, which allows the toxicity assessment (Table 2).

The conditions of practical application of ENFET biosensors based on inhibitory analysis were investigated and critically evaluated for optimisation. The enzyme reactivation after inhibition by organophosphorous pesticides was demonstrated when using pyridine-2-aldoxime methyliodide (PAM-2) [9, 30]. At the enzyme inhibition by hypochlorite species, PAM-2 treatment did not give a restoration effect. This fact can be used as a selectivity test for discrimination of inhibition by organophosphorous pesticides or hypochlorite species.

Reversible inhibition of cholinesteras e s. Steroidal glycoalkaloids (e. g., $\alpha$-solanine, $\alpha$-chaconine) are natural neurotoxins, the main source of which are the plants of family Solanaceae, including potato, widely used in food by millions of people. Consumption of potatoes and potato products can be potentially dangerous because high concentrations of steroidal gly- 

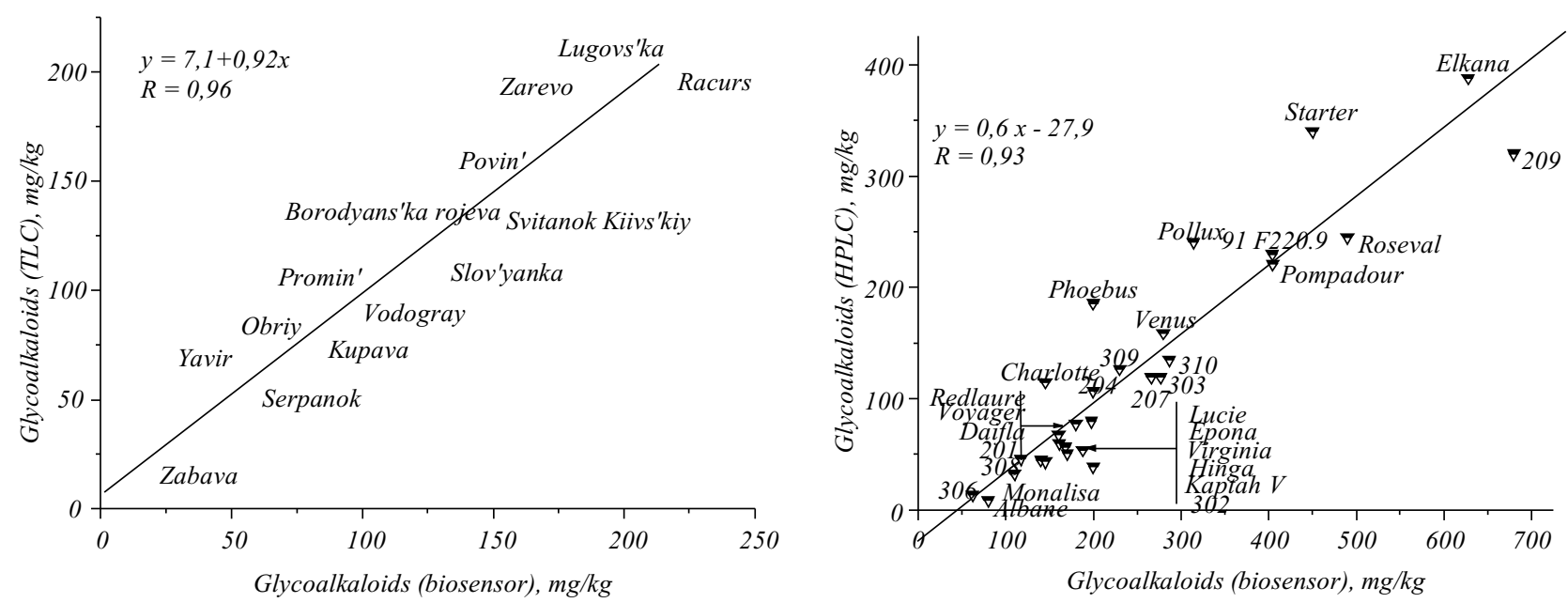

Fig. 2. Correlation between data on total glycoalkaloid content obtained by biosensor and thin layer chromatography $(A)$, biosensor and HPLC $(B)$ in potato tubers of $A-$ Ukrainian and $B$-French varieties

coalkaloids lead to poisoning, sometimes with fatal outcome, for both humans and animals [37]. Glycoalkaloids cause double toxic effects, firstly, as detergents, destroying cell membranes, and second, inhibiting cholinesterases, which play a key role in the transmission of nerve impulses. Thus, continuous monitoring of the glycoalkaloids level in food is considered to be of extreme importance.

The determination of alkaloids concentrations by biosensors is based on the alkaloids ability to inhibit $\mathrm{BuChE}$ reversibly. The potentiometric biosensor with ISFETs and immobilized BuChE was developed for the express analysis of the glycoalkaloid total content which ranges within $0.2-100 \mu \mathrm{M}$ depending on the type of alkaloid, low detection limits of $0.2 \mu \mathrm{M}$ for $\alpha$-chaconine, $0.5 \mu \mathrm{M}$ for $\alpha$-solanine, and $0.5 \mu \mathrm{M}$ for tomatine [32-35]. Glycoalkaloids were measured in potato and tomato juices by two methods, namely standard additions and using a calibration curve [36, 37]. Comparison of the results of biosensor determination with the data of thin film chromatography and HPLC analysis (Fig. 2) showed a high correlation. The biosensor developed is sensitive and highly reproducible, it provides simple and quick direct screening of glycoalkaloids in fresh potato and tomato juices without any sample pretreatment. Thus, it can be considered as a basis for the development of a commercial device for the express analysis of total glicoalcaloids in potato tubers of existing varieties and those obtained by selection or genetic modification, as well as in foodstuffs.
Multibiosensor for ecological monitoring of tox i c compounds. We were the first to propose the conception of toxins determination by a multibiosensor based on the enzyme inhibition analysis [10]. The multibiosensor with a matrix of ISFETs and several bioselective elements (AcChE, BuChE, urease, glucose oxidase, and three-enzyme system - invertase, mutarotase, glucose oxidase) was developed and its main charateristics were examined [40-43]. The results of inhibition of the enzyme system by different concentrations of individual toxicants and their mixtures were analyzed by the methods of mathematical statistics to develop the approach to quantitative or semi-quantitative determination of toxicants in real water samples of the environment [42].

On the basis of this multibiosensor, we created a portable laboratory device to analyze real water samples from a number of Kyiv water reservoirs, and complex multicomponent water assays from the landfill waste for the presence of toxic substances [43]. A comparison of the sensor data with traditional methods shows a high degree of correlation (Table 3) [43].

The developed multibiosensor can serve as a basis for designing and industrial manufacture of measuring apparatus for express integral and selective determination of water pollutants.

Conductometric biosensors. The biosensors based on conductometric principle seem to be very advantageous in several aspects: i) thin-film electrodes are suitable for miniaturisation and large scale production 
Comparison of different methods of the analysis of real samples of the environment [43]

\begin{tabular}{|c|c|c|c|c|}
\hline \multirow{2}{*}{ Place of sampling } & \multicolumn{3}{|c|}{ Traditional methods, mg/l } & \multirow{2}{*}{ Multibiosensor method } \\
\hline & $\mathrm{AAAHg}^{2+}$ & AAS & TLC & \\
\hline Vyrlytsia (Poznyaki, Kyiv) & - & - & - & - \\
\hline Vyrlytsia $+400 \mathrm{nM} \mathrm{Hg}^{2+}$ & 0.079 & - & - & + \\
\hline Dnieper river (Osokorki, Kyiv) & - & - & - & - \\
\hline Dnieper river $+10 \mu \mathrm{M}$ trichlorfon & - & - & 2.57 & + \\
\hline Solnechnoe (Osokorki, Kyiv) & - & - & - & - \\
\hline Solnechnoe $+5 \mu \mathrm{M} \mathrm{Cu}^{2+}$ & - & $0.321\left(\mathrm{Cu}^{2+}\right)$ & - & + \\
\hline Ministerske (Obolon, Kyiv) & - & - & - & - \\
\hline Opechen (Obolon, Kyiv) & - & - & - & - \\
\hline Opechen lower (Obolon, Kyiv) & - & - & - & - \\
\hline Verbne (Obolon, Kyiv) & - & - & - & - \\
\hline Dnieper gulf (Obolon, Kyiv) & - & - & - & - \\
\hline Dnieper (Obolon, Kyiv) & - & - & - & - \\
\hline \multirow{4}{*}{$\begin{array}{c}\text { Landfill waste N 5, Pidgirtsi village, } \\
\text { Obukhivski, Kyiv region }\end{array}$} & \multirow{4}{*}{-} & $0.317\left(\mathrm{Cu}^{2+}\right)$ & \multirow{4}{*}{-} & \multirow{4}{*}{+++} \\
\hline & & $0.034\left(\mathrm{Co}^{2+}\right)$ & & \\
\hline & & $1.471\left(\mathrm{Zn}^{2+}\right)$ & & \\
\hline & & $0.988\left(\mathrm{Cr}^{2+}\right)$ & & \\
\hline
\end{tabular}

$\mathrm{N}$ o t e s. $\mathrm{AAAHg}^{2+}$ - atomic absorption mercury analyzer; AAS - atomic absorption spectroscopy; TLC - thin layer chromatography; «+» exceeding MPC; «++»- exceeding MPC by several orders of magnitude.

by inexpensive technology; noble metals can be changed for cheaper ones, e. g. Ni; ii) there is no need in reference electrode, no light sensitivity, small driving voltage decreases power consumption; iii) large spectrum of analytes of different nature can be determined on the basis of various reactions and mechanisms.

The method of solution conductance monitoring was originally developed for determining chemical reaction rates and only recently it has been applied to the reactions catalysed by enzymes, namely, hydrolases, proteases, oxidases, amidases, peptidases, etc. [44].

Taking into consideration the mentioned attractive features of conductometric principle and simplicity of corresponding devices, we directed our efforts on the development of conductometric biosensors with improved working characteristics.

Enzyme-based biosensors. The enzyme-based conductometric biosensors can be used for both direct and inhibitory analysis. In the last years we developed a number of enzyme conductometric biosensors for determination of main natural metabolites and toxins, created their laboratory prototypes, and optimized them for real samples. The main analytical characteristics are presented in Table 4.

In these biosensors we applied conductometric transducers consisting of two pairs of planar interdigitated electrodes, produced by vacuum deposition of gold or platinum on a ceramic support. Immobilized enzymes, either individual ones or their cascade, served as bioselective elements. Immobilization of enzymes with BSA on the transducer surface was performed by glutaraldehyde crosslinking. The bioselective membranes composition and the conditions of enzyme immobilization were optimized.

We developed conductometric biosensors based on direct analysis for determination of glucose, urea, ace- 
Table 4

Analytical characteristics of the conductometric enzyme biosensors*

\begin{tabular}{|c|c|c|c|c|c|c|}
\hline \multirow{2}{*}{ Substrate/inhibitor (enzyme) } & \multirow{2}{*}{ Dynamic range, $\mathrm{M}$} & \multirow{2}{*}{ Operational mode } & \multirow{2}{*}{$\begin{array}{c}\text { Time of } \\
\text { analysis, min }\end{array}$} & \multicolumn{2}{|c|}{ Stability } & \multirow{2}{*}{ References } \\
\hline & & & & Operational, h & Storage, day & \\
\hline \multicolumn{7}{|c|}{ Substrate analysis } \\
\hline Glucose (Glucose Oxidase) & $10^{-4}-3 \cdot 10^{-3}$ & $\begin{array}{c}\text { Kinetic } \\
\text { Steady-state }\end{array}$ & $\begin{array}{c}0.1-0.2 \\
1-2\end{array}$ & $>20$ & 90 & {$[45]$} \\
\hline Urea (Urease) & $10^{-4}-5 \cdot 10^{-3}$ & $\begin{array}{c}\text { Kinetic } \\
\text { Steady-state }\end{array}$ & $\begin{array}{c}0.1-0.2 \\
1-3\end{array}$ & $>20$ & 30 & {$[45]$} \\
\hline $\begin{array}{l}\text { Acetylcholine chloride (Acetylcholine } \\
\text { Esterase) }\end{array}$ & $10^{-4}-1.2 \cdot 10^{-2}$ & $\begin{array}{c}\text { Kinetic } \\
\text { Steady-state }\end{array}$ & $\begin{array}{c}0.1-0.2 \\
1-2\end{array}$ & $>10$ & 30 & {$[46]$} \\
\hline $\begin{array}{l}\text { Butyrylcholine chloride (Butyrylcholine } \\
\text { Esterase) }\end{array}$ & $10^{-4}-10^{-2}$ & $\begin{array}{c}\text { Kinetic } \\
\text { Steady-state }\end{array}$ & $\begin{array}{c}0.1-0.2 \\
1-2\end{array}$ & $>10$ & 30 & {$[46]$} \\
\hline Penicillin (Penicillinase) & $10^{-4}-1.5 \cdot 10^{-2}$ & Steady-state & 1 & $>20$ & 90 & {$[11]$} \\
\hline Formaldehyde (Alcohol Oxidase) & $0.1-5 \mathrm{mg} / \mathrm{ml}$ & Steady-state & $1-2$ & $>2$ & 30 & {$[47,48]$} \\
\hline Arginine (Arginase + Urease) & $0.1-5 \mathrm{mg} / \mathrm{ml}$ & Steady-state & $1-2$ & $>2$ & 30 & {$[49]$} \\
\hline \multicolumn{7}{|c|}{ Inhibitory analysis } \\
\hline $\mathrm{Hg}^{2+}$ (urease) & $10^{-6}-5 \cdot 10^{-5}$ & Kinetic & $20 * *$ & Disposable & 30 & {$[50,51]$} \\
\hline $\mathrm{Cu}^{2+}$ (urease) & $2 \cdot 10^{-6}-10^{-4}$ & Kinetic & $20 * *$ & Disposable & 30 & {$[50,51]$} \\
\hline $\mathrm{Cd}^{2+}$ (urease) & $5 \cdot 10^{-6}-2 \cdot 10^{-4}$ & Kinetic & $20 * *$ & Disposable & 30 & {$[50,51]$} \\
\hline $\mathrm{Co}^{2+}$ (urease) & $10^{-5}-5 \cdot 10^{-4}$ & Kinetic & $20 * *$ & Disposable & 30 & {$[50,51]$} \\
\hline $\mathrm{Pb}^{2+}$ (urease) & $2 \cdot 10^{-5}-5 \cdot 10^{-3}$ & Kinetic & $20 * *$ & Disposable & 30 & {$[50,51]$} \\
\hline $\mathrm{Sr}^{2+}$ (urease) & $10^{-4}-5 \cdot 10^{-3}$ & Kinetic & $20 * *$ & Disposable & 30 & {$[50,51]$} \\
\hline DFP (AChE) & $5 \cdot 10^{-11}-10^{-7}$ & Steady-state & $15^{* *}$ & $>2$ & 30 & {$[50,51]$} \\
\hline Trichlorfon (AChE) & $5 \cdot 10^{-7}-10^{-5}$ & Steady-state & $15 * *$ & $>2$ & 30 & {$[50,51]$} \\
\hline Paraoxon-ethyl (AChE) & $10^{-8}-10^{-4}$ & Steady-state & $15 * *$ & $>2$ & 30 & {$[46,51]$} \\
\hline Paraoxon-methyl (AChE) & $5 \cdot 10^{-7}-10^{-4}$ & Steady-state & $15 * *$ & $>2$ & 30 & {$[46,51]$} \\
\hline Diuron (tyrosinase) & $1-2000 \mathrm{ppb}$ & Steady-state & $15 * *$ & Disposable & 30 & {$[52]$} \\
\hline Atrazine (tyrosinase) & $1-2000 \mathrm{ppb}$ & Steady-state & $15 * *$ & Disposable & 30 & {$[52]$} \\
\hline
\end{tabular}

$\mathrm{N}$ o t e. $*$ Without additional charged membranes; $* *$ measurement time includes preincubation with inhibitor.

tylcholine, butyrylcholine, penicillin, formaldehyde, arginine, etc. (Table 4). The changes of conductivity during enzymatically catalysed conversion of the substrate are proportional to its concentration:

$$
\text { Appropriate }
$$

$$
\begin{aligned}
& \text { Substrate } \rightarrow \text { Charged product(s) } \\
& \text { Enzyme }
\end{aligned}
$$

and can be registered by the conductometric sensor system.

The conductometric enzyme biosensors, using inhibitory analysis, were created for determination of organophosphorous pesticides and heavy metal ions. The scheme of pesticides detection is based on their ability to inhibit the AcChE and BuChE activity by phos- 
phorylating serine $\mathrm{OH}^{-}$groups in the enzyme active sites. In the case of heavy metal determination, immobilised urease can be inactivated by heavy metal ions via their direct interaction with the thiol group of the enzyme active site.

The assay protocol included measurement of the biosensor response to a fixed concentration of the specific substrate before and after the biosensor incubation in a solution containing the toxic compound.

The biosensors demonstrated reproducible and stable responses to substrates and inhibitors with a measurement time of 0.5-2 min for direct and 15-20 min for inhibitory analysis. Influence of $\mathrm{pH}$, buffer capacity and ionic strength was studied [45-49]. Responses of the conductometric enzyme sensors presented in Table 4 were shown to be strongly dependent on buffer capacity and ionic strength. We tested different additional membranes, which may control diffusion of substrates and products of the biochemical reaction for optimizing sensor operation to satisfy practical requirements [53].

It is noteworthy that the urease- and cholinesterasebased conductometric biosensors may also serve as a reliable tool to evaluate the overall toxicity of liquid samples $[46,50,51]$. The conductometric AcChE-based biosensor was applied for control of organophosphorous pesticides photodegradation. Fig. 3 shows a correlation between HPLC measurement of parathionmethyl photodegradation and the toxicity of sample solution obtained by the biosensor $[54,55]$. As the curve 4 shows, the inhibition effect registered by the biosensor increases dramatically as soon as photodegradation begins. In addition, the toxicity curve does not exactly follow the curve of appearance of paraoxon-methyl, which is more toxic toward $\mathrm{AcChE}$ than the precursor pesticide.

The maximal sample toxicity is obtained about 40 min after UV irradiation. It is important that even after almost complete degradation of parathion-methyl $(t>$ $160 \mathrm{~min}$ ) the mixture still exhibited a relatively high toxicity, mainly due to paraoxon-methyl. Such information can not be obtained by traditional methods of analysis.

Biosensors based on enzyme cascades. Determination of mono- and disaccharides (carbohydrates) at different stages of technological processes is necessary in food and beverages industry (sugar, dairy, wine production), breweries, agriculture, pharmaceutical manufacture, etc.

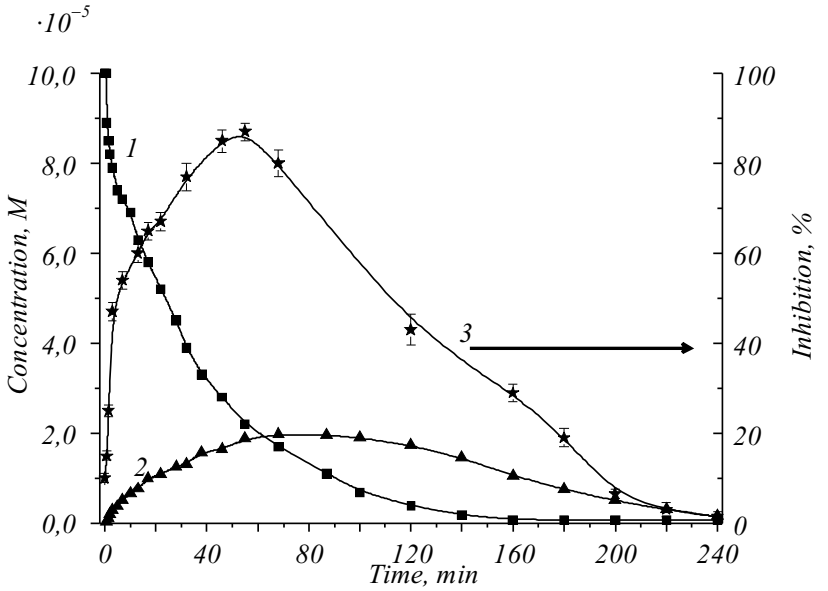

Fig. 3. UV photodegradation of parathion-methyl: 1 - disappearance of parathion-methyl; 2 - evolution of paraoxon-methyl; 3 - toxicity assessed by the AcChE biosensor

In recent years, we first developed new conductometric biosensors based on enzyme cascades to identify major natural saccharides - sucrose, maltose, lactose with three-enzyme system (mutarotase, glucose oxidase, and related glycosidases (invertase, $\alpha$-glucosidase, $\beta$-galactosidase, respectively), and glucose - with only one enzyme - glucose oxidase [78-80]. The laboratory prototypes were created and optimized for real samples, the analytical procedure was worked out. The content of sucrose and glucose in samples of sugary drinks and juices was analyzed by the sucrose and glucose biosensors, a good correlation of the results with the HPLC data was shown $(R=0.996)$. The same biosensors were used to determine the content of sucrose and glucose in samples of sugar beet homogenate. The results were in good correlation with those of polarimetric method commonly used in sugar production to measure sucrose in sugar beet $(R=0.914)$.

Thus, the developed biosensor can be employed as a basis for industrial production of analytical tools for selective determination of maltose, sucrose, lactose and glucose. Application of such biosensors in food, pharmaceutical, biotechnical industries, agriculture, etc., can significantly simplify and improve the analysis of carbohydrates.

Cell-based biosensors. The yeast cell-based conductometric biosensor was developed for the ethanol quantification in alcoholic beverages [59]. When ethanol is added to the tested solution, the alcohol molecules penetrating through a cell membrane are oxidised 


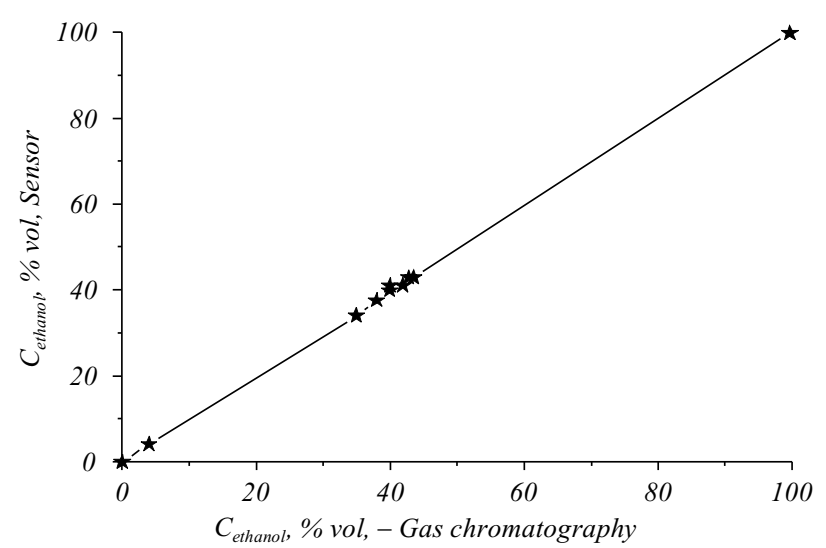

Fig. 4. Results of ethanol determination in different alcoholic beverages (beer (1), vodka (2), cognac (3) and spirit (4))

by methylotrophic yeast Candida boidinii 706 (wild type) in two steps. First, alcohol dehydrogenase (type II) catalyses formation of acetaldehyde in oxidative utilisation of ethanol. Then, acetaldehyde is converted to acetic acid by acetaldehyde dehydrogenase. The resulting conductivity changes due to specific acidic metabolite secretion out of the membrane are registered by the sensor system.

The results of ethanol determination in different diluted alcoholic beverages by the cell-based biosensor are presented in Fig. 4 in comparison with those obtained by gas chromatography. Good correlation is shown $(R=$ $=0.9988)$.

A bi-enzymatic conductometric biosensor with immobilised Chlorella vulgaris microalgae as bioreceptors was described in [60, 61]. The use of micro-organisms for multi-detection can be a good alternative, since each living cell contains a large number of enzymes. Local conductivity variations caused by the algae alkaline phosphatase and AcChE activities were detected. These two enzymes are known to be inhibited by distinct families of toxic compounds: alkaline phosphatase - by heavy metals, AcChE - by carbamates and organophosphorous pesticides.

It was shown that these biosensors are quite sensitive to $\mathrm{Cd}^{2+}$ and $\mathrm{Zn}^{2+}$ (the detection limit is 10ppb for a 30-min exposure). For pesticides, the experiments showed that paraoxon-methyl inhibits AChE of C. vulgaris contrary to parathion-methyl and carbofuran. The biosensors were then exposed to different mixtures $\left(\mathrm{Cd}^{2+} / \mathrm{Zn}^{2+}\right.$, $\mathrm{Cd}^{2+} /$ paraoxon-methyl) but neither synergistic nor antagonistic effect could be observed. A good repeatability was obtained - relative standard deviation did not exceed $8 \%$, the response time was 5-7 min.

Capacitance biosensors and numerical evaluation of their analytical parameters. One of the most crucial problems arising in practical application of potentiometric and conductometric biosensors is a dramatic decrease in the sensor response when the buffer concentration of the measured sample increases. The same phenomenon has been observed for the formaldehyde-specific sensor based on recombinant formaldehyde dehydrogenase when measuring capacitance versus voltage [62]. The numerical simulation of the obtained experimental results using the classical site-binding model (Eq. 1) has shown that the resulted theoretical curve does not completely fit the experimental observations.

$$
\begin{gathered}
P\left[X^{Z+}\right]=-\log \left[X^{Z+}\right]=\frac{Z q \psi_{0}}{2.3 K T}+ \\
+\log \left(\frac{q N s}{C_{e q} \psi_{0}}-1\right)-p K
\end{gathered}
$$

where $\psi_{0}$ is the potential of the functionalized insulator/ electrolyte interface, $N_{S}$ is the surface density of sites, $p K$ is the complexation constant, $C_{e q}$ is the double layer capacitance, and $Z$ is the charge of the ionic species.

We suggested that classical model should be improved, since it does not take into account the phenomenon of specific adsorption of counter ions and, consequently the bio-recognition membrane potential fluctuations. To describe the membrane fractality effect we introduced a scale law term:

$$
\mathrm{S}(\mathrm{C})=\alpha \mathrm{C}^{-\beta},
$$

where $S$ is the sensor output signal, $C$ is the buffer concentration in bulk solution, $\alpha$ and $\beta$ are the parameters fitting.

The addition of the above mentioned scale effect term, which is attributed to the fractal nature of membrane/electrolyte interface in the Eq. 1, allowed us to get the modified equation for site-binding model:

$$
\begin{gathered}
P\left[X^{Z+}\right]=-\log \left[X^{Z+}\right]=\frac{Z q \psi_{0}}{2.3 K T}+ \\
+\log \left(\frac{q N s}{C_{e q} \psi_{0}}-1\right)-p K+\alpha C^{-\beta} .
\end{gathered}
$$


Table 5

Characteristics of $\mathrm{Si} / \mathrm{SiO}_{2} / \mathrm{Si}_{3} \mathrm{~N}_{4} / r F D H$ formaldehyde sensors in different buffers

\begin{tabular}{|c|c|c|c|c|c|c|c|}
\hline Transducer & $\begin{array}{l}\text { Bio-recognition } \\
\text { molecule }\end{array}$ & Buffer type & $\begin{array}{l}\text { Sensitivity, } \\
\mathrm{mV} / \text { decade }\end{array}$ & $\mathrm{pK}$ & $\mathrm{Ns}$, sites $/ \mathrm{cm}^{2}$ & $\alpha$ & $\beta$ \\
\hline \multirow[t]{2}{*}{$\mathrm{Si} / \mathrm{SiO}_{2} / \mathrm{Si}_{3} \mathrm{~N}_{4}$} & $\mathrm{rFDH}$ & Borate & 37 & 5.8 & $5 \cdot 10^{17}$ & $2.1 \cdot 10^{-4}$ & 0.9 \\
\hline & & Tris & 2.5 & 2.1 & $7 \cdot 10^{15}$ & $25 \cdot 10^{-4}$ & 0.9 \\
\hline
\end{tabular}

The numerical simulation of the obtained data using modified equation has resulted in theoretical curves fitting well the experimental data.

The response of the formaldehyde-sensitive biosensor has also been examined in Borate and Tris buffers, $\mathrm{pH}$ 8.4. It has been shown that in Tris buffer the $C(V)$ curves reveal a weak shift of the initial $C(V)$ (without formaldehyde injection) and consequently a variation of the flat-band potential $(\triangle V F B)$ to positive bias at increasing formaldehyde concentration, while the opposite behavior has been monitored in Borate buffer [62]. We have suggested a change in the mechanism of the signal generation due to the enzymatic transformation of formaldehyde in Tris buffer. Moreover, the biosensor sensitivity in Tris buffer decreased dramatically and became only $2.4 \mathrm{mV}$ per decade (more than ten times lower than that obtained in Borate buffer). The first phenomenon was explained by the different nature of the used buffers: for Boric buffer - weak acid and for Tris one - weak base are responsible for pH-buffering, so different charge of $\mathrm{pH}$-forming ions (anionic - for Borate, and cationic - for Tris) and their different interaction with bio-functionalized surface could result in opposite direction of the curves' shift. The drastic drop in sensitivity of the bio-membrane response to formaldehyde in Tris buffer was explained by chemical interaction of the Tris-base with formaldehyde [12], masking the target analyte from enzymatic conversion to formic acid. The numerical simulation of the obtained results using modified site-binding model has resulted in theoretical calibration curves, which are in full agreement with the experimental data.

The calculated number of sites (NS) available for binding the charged molecules released due to the enzymatic FA transformation is $5 \cdot 10^{17}$ sites $/ \mathrm{cm}^{2}$ in Borate buffer and $7 \cdot 10^{15}$ sites $/ \mathrm{cm}^{2}$ in Tris buffer. These values are the additional proofs of the described above observations and explanations. The key characteristics and fitting parameters of the capacitive formaldehyde bio- sensor with Borate and Tris buffers are summarized in Table 5. We envisage that our adjusted site-binding model can also be applied further for the analysis of analytical parameters of potentiometric and conductometric sensors owing to the similarity in sensor signal generation mechanisms (charged ion species production/consumption).

Amperometric enzyme biosensors. The functioning of amperometric biosensors is based on enzymatic reactions where the concentrations of electroactive substrates/products change. These variations can be measured directly by an amperometric transducer. The enzymes generally catalyzing reactions of this kind are various oxidoreductases. The scheme of such reactions is:

$$
\begin{gathered}
S+E_{\mathrm{FAD}} \Leftrightarrow E_{\mathrm{FAD}} S \Rightarrow E_{\mathrm{FADH} 2}+P ; \\
E_{\mathrm{FADH} 2}+\mathrm{O}_{2} \Rightarrow E_{\mathrm{FAD}}+\mathrm{H}_{2} \mathrm{O}_{2} .
\end{gathered}
$$

Most of amperometric sensors of this kind operate at the potential of $+0.65-+0.9 \mathrm{~V}$.

Biosensors for determination of main components of wine. Ethanol, glycerol, glucose and lactate are important components of wine, their concentration is an indicator of quality, naturalness, taste and stability of drinks. Traditionally, wine components are analyzed by chromatographic, enzymatic, spectrophotometric, refractometric, densitometric methods, capillary electrophoresis, etc. Biosensors providing express, highly sensitive, selective and cheap analysis can be a promising modern alternative.

We developed enzyme amperometric biosensors for determination of lactate, glucose, glycerol and ethanol, designed their laboratory prototypes and specified the main analytical characteristics (Table 6) [63-67].

Along with the development of monobiosensors, there is a need for simultaneous determination of several analytes. The creation of multibiosensor combining a series of sensitive elements on a single chip is an actual 
Analytical characteristics of developed amperometric biosensors

\begin{tabular}{|c|c|c|c|c|c|c|}
\hline \multirow{2}{*}{ Substrate (enzyme) } & \multirow{2}{*}{ Dynamic range, $\mathrm{mM}$} & \multirow{2}{*}{ Operational mode } & \multirow{2}{*}{$\begin{array}{c}\text { Time of } \\
\text { analysis, min }\end{array}$} & \multicolumn{2}{|c|}{ Stability } & \multirow{2}{*}{ References } \\
\hline & & & & Operational, $\mathrm{h}$ & Storage, day & \\
\hline Glucose (Glucose Oxidase) & $0.03-8$ & Steady-state & $1-3$ & $>20$ & 90 & {$[63,64]$} \\
\hline Lactate (Lactate Oxidase) & $0.004-0.5$ & Steady-state & $1-3$ & $>20$ & 25 & {$[63,64]$} \\
\hline Ethanol (Alcohol Oxidase) & $0.08-1$ & Steady-state & $1-3$ & $>120$ & 33 & {$[63,64,66]$} \\
\hline Glycerol (Glycerol Oxidase) & $0.001-25$ & Steady-state & $1-3$ & $>30$ & 40 & [67] \\
\hline \multicolumn{7}{|l|}{ Multisensor detection: } \\
\hline Lactate (Lactate Oxidase) & $0.0005-0.64$ & \multirow{3}{*}{ Steady-state } & \multirow{3}{*}{$1-5$} & \multirow{3}{*}{$>20$} & \multirow{3}{*}{32} & \multirow{3}{*}{ [63] } \\
\hline Ethanol (Alcohol Oxidase) & $0.1-6.4$ & & & & & \\
\hline Glucose (Glucose Oxidase) & $0.0005-1.6$ & & & & & \\
\hline
\end{tabular}

challenge. Therefore, we developed an amperometric enzyme multibiosensor and designed its portable laboratory prototype for wine quality control. It had the linear ranges of $0.005-0.8 \mathrm{mM}$ lactate, $0.01-6.4 \mathrm{mM}$ ethanol, $0.005-1 \mathrm{mM}$ glucose, and sufficient storage stability. The developed system was tested in the analysis of real samples of wine products. The procedure of standardization of mono- and multisensor devices for measurements in vegetable and fruit juices and wines has been launched.

Amperometric biosensors for biomedical purpose. One more field of scientific interest of our laboratory was the research aimed at the development of microbiosensors of biomedical application for analysis of neurotransmitters and metabolites. A number of amperometric microbiosensors based on various enzyme systems were developed for determination of acetylcholine, choline, glutamate, D-serine, glucose, lactate, and ATP (Table 7) [68-72]. In these biosensors we used the amperometric transducers produced in our laboratory on the basis of monocarbon fiber and platinum wire. To increase sensitivity, the carbon-based transducers were modified by electrochemically deposited ruthenium. The biosensor selectivity was increased by electrodeposition of an additional polyphenylenediamine membrane on the transducer surface. The main analytical characteristics of the developed microbiosensors are given in Table 7. Some of the developed microbiosensors were successfully used to monitor the secretion of neurotransmitters (glutamate, D-serine) by the cell cultures of astrocytes, and in vivo - to determine the level of neurotransmitters and metabolites (glucose, lactate, glutamate) in the brain of rats.

The microbiosensors designed for ATP determination can be also used in the development of drugs based on inhibitors of certain target enzymes such as kinases, synthetases and other enzymes for which ATP is a substrate. The electrochemical biosensor will enable rapid analysis of ATP level without using radiolabeled products that will significantly improve the working conditions.

Application of nanomaterials for enhancement of analytical characteristics of biosensors. Immobilization is the key-step in biosensor construction. However, in general the conventional methods of biomolecule immobilization (physical adsorption, covalent binding, cross-linkings and entrapment in gels or membranes) have some disadvantages - low reproducibility and stability of bioselective elements, poorly controlled spatial deposition. In this context, the use of nanomaterials for the construction of biosensing devices is one of the most exciting approaches. The extremely promising prospects of these devices accrue from the unique properties of nanomaterials.

Application of zeolites. Zeolites are potentially helpful for the biosensor development due to their specific properties - low toxicity, chemical, mechanical and thermostability, tolerance to microorganisms [73]. Moreover, a wide range of modifications allows obtaining zeolites with improved properties. 
Table 7

The developed biosensors for biomedical application

\begin{tabular}{|c|c|c|c|c|}
\hline Enzymatic system & Transducer & Specificity & $\begin{array}{l}\text { Linear dynamic } \\
\text { range, } \mathrm{mM}\end{array}$ & References \\
\hline GOD & Carbon fiber electrode + ruthenium layer + poly $-m-\mathrm{PD}$ & Glucose & $0.1-4$ & {$[68]$} \\
\hline LOD & Carbon fiber electrode + ruthenium layer + poly- $m-\mathrm{PD}$ & Lactate & $0.1-2.0$ & [68] \\
\hline ChOD & Carbon fiber electrode + Os-based Red-Ox hydrogel electrode & Choline & $0.01-0.5$ & [69] \\
\hline $\mathrm{ChOD}+\mathrm{AcChE}$ & Carbon fiber electrode + Os-based Red-Ox hydrogel electrode & $\begin{array}{l}\text { Choline }+ \\
\text { Acetylcholine }\end{array}$ & $0.01-0.5$ & [69] \\
\hline GIOD & $\begin{array}{c}\text { Carbon fiber electrode }+ \text { ruthenium layer }+ \text { poly- } m-\mathrm{PD}+\text { Nafion and } \\
\text { polyurethane }\end{array}$ & L-glutamate & $0.001-0.1$ & {$[68,70]$} \\
\hline Hexokinase + GOD & Platinum electrode + poly- $m-\mathrm{PD}$ & D-serine & $0.0001-0.05$ & {$[71]$} \\
\hline Oxidase of D-AA & Platinum electrode + poly- $m-\mathrm{PD}$ & $\begin{array}{l}\mathrm{ATP}+ \\
\text { glucose }\end{array}$ & $0.0025-2.5$ & {$[72]$} \\
\hline
\end{tabular}

Zeolites can be embedded into the bioselective elements to improve analytical characteristics of biosensors, i. e. their sensitivity to the substrate, linear detection range, signal reproducibility. We applied zeolites of various kinds as alternative carriers for enzyme immobilisation [74-76]. It was shown, that use of zeolites allowed optimization of sensitivity, selectivity and stability of glucose amperometric biosensors and urea potentiometric and conductometric biosensors [74-76].

Promising results were obtained when using natural zeolites clinoptilolite and silicalite [77-80]. The developed clinoptilolite-based biosensors [77-79] demonstrated high operational stability (the coefficient of variation was within the range $0.8-7 \%$ ) and storage stability for about five months. In silicalite-based biosensors, urease was physically absorbed on zeolite by simple and fast procedure without toxic and auxiliary compounds. These biosensors were characterized by improved intra(RSD $9 \%$ ) and inter- (RSD $4 \%$ ) reproducibility and operational stability (less than $10 \%$ loss of activity after 10 days).

Application of carbon nanomaterials. The application of carbon nanomaterials in the elaboration of biosensors is among novel trends in modern analytical biotechnologies. Ultra-low sizes of carbon nanotubes and nanodiamonds, large specific surface area, the possibility of their modification by active groups, good biocompatibility, low toxicity and good electrical conductivity provide for active application of these materials in targeted management of the key analytical characteris- tics of biosensors, in particular, for the enhancement of their stability, sensitivity and selectivity. In recent years the laboratory has elaborated a number of highly sensitive and stable amperometric sensors based on nanocomposite biomembranes using carboxylated and aminated carbon nanotubes and detonation nanodiamonds [1820]. In particular, the biosensor, based on gold printed amperometric electrodes («DropSens», «Llanera» («Asturias»), Spain) and immobilized glucose oxidase using multi-walled carbon nanotubes (MWCNT) was developed for the purpose of detecting glucose in wine. It was demonstrated that the introduction of MWCNT to the amperometric biosensor membrane promotes the increase in the signal value, expands the linear range of glucose concentration evaluation and allows evaluating the substrate in a wide range of working potential $(0.3-0.8 \mathrm{~V})$. Several amperometric sensors were elaborated on the basis of nanocomposite sensitive elements, based on immobilized choline oxidase for quantitative estimation of choline. The sensitivity of the elaborated biosensor is $500.0 \mu \mathrm{A} \mathrm{M}^{-1} \mathrm{~cm}^{-2}$, the minimal reporting concentration of choline is $0.3-0.4 \mu \mathrm{M}$, the linear range of choline concentration evaluation is in the range of 0.3 up to $500 \mu \mathrm{M}$ of analyte. It was demonstrated that the introduction of MWCNT into the enzyme-containing membrane structure contributes to the significant enhancement of its storability (after storing for five months in $100 \mathrm{mM}$ phosphate buffer, $\mathrm{pH} 7.9$ at $4{ }^{\circ} \mathrm{C}$ the residual activity of the enzyme is $70 \%$ ). It is also noteworthy that the application of nanocomposite memb- 


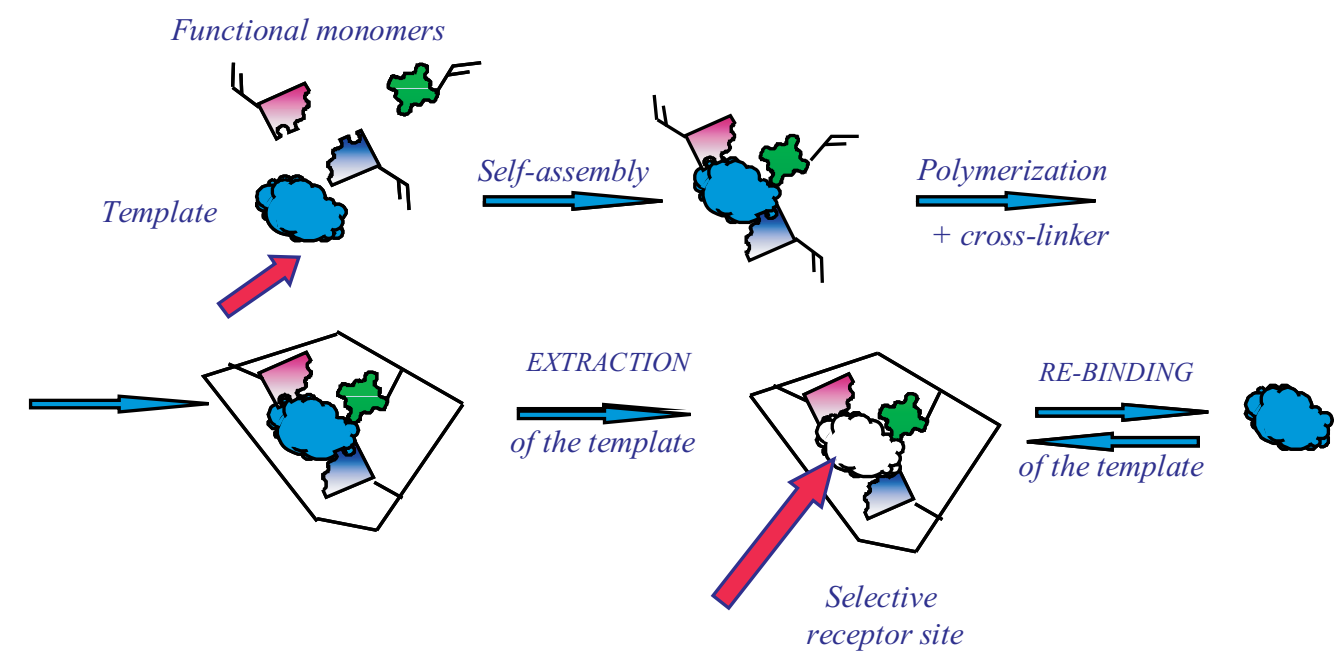

Fig. 5. The scheme of formation of molecularly imprinted polymers ranes, based on carbon nanomaterials and conductive polymers allows creating bioselective membranes with complex architecture. We have optimized the method of obtaining a multilayer membrane, based on Nafion film (1\%) with nanodiamonds ( $1 \%)$ on the surface of carbon electrodes, modified by cobalt phthalocyanine, and choline oxidase, immobilized into protein gel, for quantitative determination of choline. It was demonstrated that the modification of carbon electrodes with a film, based on nanodiamonds, provides for the three-fold increase in the sensitivity of substrate detection and the decrease in the minimal reporting choline concentration. The above mentioned results of investigations lead us to the following generalizing conclusion: the application of carbon nanomaterials and nanocomposite bioselective membranes on their basis is a promising trend both for the elaboration of new amperometric sensors and the improvement and targeted modification of their analytical characteristics. Another promising possibility is deemed to be the application of carbon nanomaterials in combination with other types of nanoparticles for the elaboration of highly organized nanocomposite membranes, which would facilitate specific targeted immobilization of bio- and chemoselective molecules of different origin practically on any surface of electrochemical, optic, acoustic and calorimetric transformers.

Biosensors based on synthetic mimics of natural antibodies and enzymes obtained by the technique of molecular imprinting. Due to high selectivity of biomolecules, that are usually used as recognition elements of biosensors, combined with high sensitivity, fast response and low cost of physical transducers, biosensor-based analytical methods are recognized to be the most effective methods of modern analytical biotechnology. However, despite the fact that many laboratory prototypes of biosensors were developed up to now, the number of commercially-available biosensors is relatively small. Apparently, that is mainly associated with low stability of all biomolecules in extreme environments. Moreover, the methods of isolation and purification of enzymes, antibodies, and receptors are quite sophisticated and time-consuming, which determines their high cost. Therefore, development of highly-selective, effective and inexpensive analytical systems without unstable biological material is of great importance. Recently artificial receptors and enzymes (polymers-biomimics) attracted significant attention of analysts working in the biosensor technology field. These materials mimic binding sites of natural antibodies and receptors as well as enzyme active centers and, at the same time, combine their high selectivity with desirable stability in aggressive media. One of the most effective approaches towards synthesis of polymers-biomimics is a technique of molecular imprinting, first reported by Wulff [83]. The method assumes synthesis of highlycross-linked polymers around so-called template molecules (the analytes of interest). Extraction of the template molecules from the fully-formed polymer results in formation of cavities in the polymeric network, which in size, shape and spatial arrangements of functional groups are complementary to the templates used in synthesis (Fig. 5). The polymers synthesized according to 
Table 8

Analytical characteristics of the MIP-based biosensors

\begin{tabular}{|c|c|c|c|c|c|}
\hline Analyte & Dynamic range, $\mathrm{M}$ & Operational mode & Time of analysis, min & $\begin{array}{l}\text { Storage stability, } \\
\text { month }\end{array}$ & References \\
\hline Atrazine & $(15-50) \cdot 10^{-9}$ & Steady-state & $6-12$ & 18 & {$[84,85]$} \\
\hline Desmetryn & $(1-30) \cdot 10^{-8}$ & Steady-state & 10 & 12 & [89] \\
\hline$o$-Hydroxyphenol & $(0.078-5) \cdot 10^{-3}$ & Steady-state & 10 & 12 & [91] \\
\hline Phenol & $(0.0005-1) \cdot 10^{-2}$ & Steady-state & 20 & 18 & [93] \\
\hline Cholesterol & $(5-50) \cdot 10^{-6}$ & Steady-state & 10 & 1 & [90] \\
\hline Aflatoxin B1 & $(1-500) \cdot 10^{-9}$ & Steady-state & 20 & 18 & [92] \\
\hline Creatinine & $(0.25-2.5) \cdot 10^{-3}$ & Steady-state & 15 & 12 & {$[93,94]$} \\
\hline
\end{tabular}

this principle are capable of subsequent recognition of the template molecules, which occurs via combination of reversible binding and shape complementarity.

Molecularly imprinted polymers (MIPs) are being traditionally used for the analytical purposes in a form of MIP particles prepared by grinding and sieving of synthesized polymer blocks or particles prepared by suspension polymerization. However, use of MIP particles in sensor technology is not effective since the majority of synthetic binding sites are loosen in course of the polymer preparation. Moreover, a number of technological problems arise during integration of polymeric particles with physical transducers. Therefore, a general approach towards synthesis of MIPs in a form of freestanding polymeric membranes and thin films on the surface of physical transducers was developed in our lab [84-88].

Using the novel approaches for MIP synthesis, conductometric, amperometric, and capacitive sensor devices were developed for detection of environmental pollutants, i. e. triazine herbicides atrazine $[84,85]$ and desmetryn [89], cholesterol [90] and $o$-hydroxyphenols [91]. The main working characteristics of the MIP-based sensors are summarized in Table 8 .

The principle of operation of all MIP-based sensors is similar to that of immunosensor devices. Biomimetics function as selective elements of the sensors, which are responsible for recognition of the analyte. MIP is immobilized on the surface of a physical transducer, which transforms a signal arising after analyte binding in the electrochemical, thermal or optical signal. The latter is proportional to the analyte concentration in the ana- lyzed sample. The interaction of MIPs with the corresponding analyte (similarly to immunosensor devices) is not accompanied with the formation of electroactive products (protons or electrons). Therefore, the sensors for direct detection of a MIP-analyte binding event are based on a change of properties of the immobilized MIP (its electrical conductivity $[84,85]$ or capacity [89]) after its interaction with the analyte.

Application of the new approaches towards MIP synthesis in a form of membranes and thin films allowed us to detect corresponding analytes in nanomolar range (Table 7). The detection limit for desmetryn, provided by the capacitive sensor based on thin MIP films, comprised $100 \mathrm{nM}$, while the linear dynamic range was 100-300 nM. The detection limit for atrazine, provided by the conductometric sensor based on free-standing MIP membranes synthesized by the method of in situ polymerization comprised $15 \mathrm{nM}$. The linear dynamic range of the conductometric sensor comprised 15-50 nM. Time of the sensor responses did not exceed 10-12 min.

The most promising approach towards development of MIP-based sensors is synthesis of polymers-biomimics that are capable of not only highly-selective recognition of corresponding analytes, but also of generation of a sensor response, which can be easily registered. From this point of view, synthesis of polymers-biomimics with catalytic properties, capable of highly-selective cleavage of the analytes of interest, is of great importance. This would provide a possibility of their effective electrochemical detection. For instance, synthetic mimics of a natural enzyme tyrosinase (EC 1.14.18.1) were synthesized by our group according to the principle of 

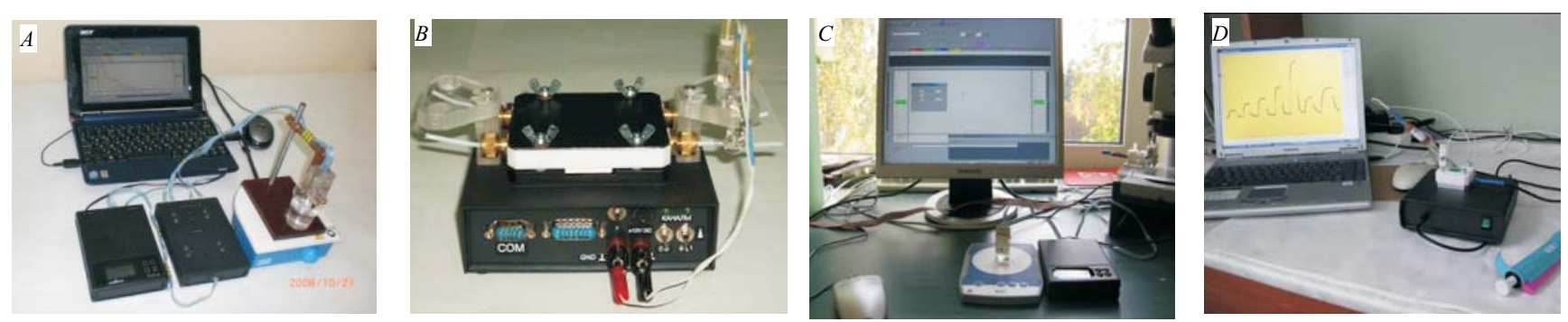

Fig. 6. The laboratory prototypes of developed biosensors: $A$ - conductometric enzyme system for determination of carbohydrates and aldehyde; $B$ - ISFET-based multisensor enzyme system for determination of toxic substances; $C$-amperometric enzyme multisensor system for analysis of quality of alcoholic and nonalcoholic beverages; $D$ - potentiometric enzyme biosensor system for determination of urea and creatinine

molecular imprinting. Taking into account literature data on a structure of tyrosinase active center, we assumed that a molecule of o-hydroxyphenol, which coordinates two $\mathrm{Cu}(\mathrm{II})$ ions at a distance of 3,6-4 C (as it is happens in a natural enzyme) can be imprinted using urocanic acid ethyl ester as a functional monomer. This functional monomer in the MIP would mimic histidine residues that are present in an active center of natural tyrosinase. The synthesized polymers-biomimics (in a form of both polymeric particles and polymeric membranes) were used as selective elements of electrochemical biosensors for express-detection of o-hydrohyphenols. Application of the polymers with the optimized composition as selective elements of electrochemical sensors allowed us to detect $o$-hydroxyphenols in aqueous solutions with the $0.078 \mathrm{mM}$ detection limit, while the linear dynamic range of the sensor comprised $0.078-5 \mathrm{mM}$.

Free-standing MIP membranes obtained by either the method of in situ polymerization or the method of photo-initiated grafting polymerization can be also used as a basis for easy-to-use optical (colorimetric or fluorescent) biosensor systems. The principle of their operation is the following. The analytes of interest are selectively adsorbed by the synthetic receptor sites in the polymer structure after filtration of the analyzed samples through the MIP membranes. The revealing of the adsorbed analytes is based either on generation of own fluorescence of the analyte after UV-irradiation of the MIP membranes.

Alternatively, the non-fluorescent analytes can be revealed through the formation of the colored complexes with the certain substances. Intensity of the MIP membranes' staining or fluorescence is proportional to the concentration of certain analytes in the analyzed samples. Fluorescent sensor systems for aflatoxin B1 detection were developed using the described principle [92]. The developed sensor systems provide aflatoxin B1 detection in the range $1-500 \mathrm{ng} / \mathrm{ml}$ with the detection limit of $1 \mathrm{ng} / \mathrm{ml}$.

Application of the computational modeling method for optimization of the polymer-biomimic composition provided synthesis of highly-selective receptors capable of selective recognition of aflatoxin B1 in mixtures containing close structural analogues of this toxin - aflatoxins $\mathrm{B} 2$ and $\mathrm{G} 2$.

Colorimetric biosensor systems for detection of phenol [93] and creatinine [94] for environmental monitoring and medical diagnostics were developed on the basis of MIP membranes obtained by the methods of in situ and grafting polymerization.

Storage stability of all the described sensors and sensor systems based on polymers-biomimics was very high and comprised 12-18 months (Table 1) for the MIP membranes stored in a dry state at room temperature. All the synthesized biomimics demonstrated extremely high selectivity, which is comparable to that of their natural counterparts.

High selectivity and stability of these materials makes them an attractive alternative to natural receptors and enzymes in biosensor technology.

Conclusions. A number of electrochemical monoand multibiosensors based on different enzymes, living cells and biomimics were developed, their laboratory prototypes were fabricated (Fig. 6) and thoroughly investigated for real conditions of application (blood serum, blood dialisate, wine and wine must, natural fruit juices, environmental water samples, etc.). It is noteworthy that electrochemical biosensors are adaptable to 
the technologies of large-scale production of miniaturised devices. Concerning further wide application of the biosensors developed, the obtained results demonstrate the possibility to modulate their main characteristics to comply with the requirements specific for potential practical purposes. Diverse biosensor modifications (with genetically modified enzymes, microorganisms, additional membranes, different nanoscaled materials, etc.) can be elaborated.

It is important, that all the biosensors designed are complementary to traditional analytical techniques. Biosensors are an additional system for fast and early warning about the presence of various substances. They can provide a way to save time and costs under urgent conditions due to a possibility of making rapid decision regarding local environmental problems or in the medical field where cheap and throw-away gadgets can be a tool for home monitoring of the patient's state or early disease diagnostics. More accurate but time-consuming and expensive classical methods could be used (if necessary) for further validation and additional investigation of the samples previously tested by biosensor arrays.

Acknowledgements. Part of the work was done in collaboration with Institute of Cell Biology, NAS of Ukraine, V. Ye. Lashkaryov Institute of Semiconductor Physics, NAS of Ukraine, Institute of Electrodynamics, NAS of Ukraine, Ecole Centrale de Lyon (France), C. Bernard University Lyon 1 (France), Middle East Technical University of Ankara (Turkey) and Institut Superieur des Sciences Appliquees et de Technologie de Sousse (Tunisia).

О. П. Солдаткін, С. В. Дзядевич, Я. І. Корпан, Т. А. Сергеєва, В. М. Архипова, О. А. Білоіван, О. О. Солдаткін, Л. В. Шкотова, О. А. Зінченко, В. М. Пєшкова, О. Я. Саяпіна, С. В. Марченко, A. В. Сльська

Біосенсори. Чверть століття досвіду науково-дослідних розробок

\section{Резюме}

Представлено огляд виконаних у лабораторії біомолекулярної электроніки досліджень в області розробки біосенсорів на основі електрохімічних перетворювачів (амперо- $i$ кондуктометричні електроди, потеціометричні $\mathrm{pH}$-чутливі польові транзистори) різних біорозпізнавальних молекул (ферменти, клітини, антитіла), біоміміків або синтетичних мембран, включаючи матричні полімери, як чутливих елементів для прямого аналізу субстратів або інгібіторного аналізу токсинів. Завдяки високій специфічності і чутливості, простоті та низькій вартості визначення різ- них речовин біосенсори є перспективними приладами для потреб охорони здоров'я, контролю довкілля, біотехнологіï, сільського господарства і харчової промисловості. Розроблено й досліджено біосенсори для прямого визначення низки аналітів та інгібіторного аналізу різних токсичних речовин. Поліпшення їхніх аналітичних характеристик можна досягти за рахунок застосування диференційного режиму вимірювань, негативно або позитивно заряджених допоміжних напівпроникних мембран, наноматеріалів різного походження, генетично модифікованих ферментів тощо. Використання цих підходів зробить можливим підвищити чутливість, селективність і стабільність біосенсорів, а також розиирити динамічний діапазон вимірювань. Упродовж останніх 25 років виготовлено більш як 50 лабораторних прототипів біосенсорних систем на основі моно- і мультибіосенсорів для прямого визначення різноманітних метаболітів та інгібіторного аналізу токсикантів. Деякі з них випробувано за умов аналізу реальних зразків. В огляді обговорено переваги і недоліки розроблених біосенсорів та розглянуто можливості їхнього практичного застосування.

Ключові слова: електрохімічний біосенсор, іммобілізований фермент, субстрат, інгібітор, мультибіосенсор.

А. П. Солдаткин, С. В. Дзядевич, Я. И. Корпан, Т. А. Сергеева,

В. Н. Архипова, О. А. Белоиван, А. А. Солдаткин, Л. В. Шкотова,

Е. А. Зинченко, В. Н. Пешкова, О. Я. Саяпина, С. В. Марченко,

А. В. Ельская

Биосенсоры. Четверть века опыта научно-исследовательских разработок

Резюме

Представлен обзор выполненных в лаборатории биомолекулярной электроники исследований в области разработки биосенсоров на основе электрохимических преобразователей (амперо- $и$ кондуктометрические электроды, потечиометрические $p H$-чувствительные полевые транзисторы) и различных биораспознающих молекул (ферменты, клетки, антитела), биомимиков или синтетических мембран, в том числе матричных полимеров, в качестве чувствительных элементов для прямого анализа субстратов или ингибиторного анализа токсинов. Благодаря высокой специфичности и чувствительности, простоте и дешевизне определения различных веществ биосенсоры представляют собой перспективный инструментарий для потребностей здравоохранения, контроля окружающей среды, биотехнологии, сельского хозяйства и пищевой промышленности. Разработаны и исследованы биосенсоры для прямого определения ряда аналитов и ингибиторного ферментного анализа различных токсичных вещееств. Улучшения их аналитических характеристик можно достичь за счет применения дифференциального режима измерений, негативно или позитивно заряженных дополнительных полупроницаемыхх мембран, наноматериалов разного происхождения, генетически модифицированных ферментов и др. Эти подходы дают возможность повысить чувствительность, селективность и стабильность биосенсоров, расширить их динамический диапазон измерений. В течение последних 25 лет изготовлено более 50 лабораторных прототипов биосенсорных систем на основе монои мультибиосенсоров для прямого определения разнообразных метаболитов и ингибиторного анализа различных токсикантов. Некоторые из них исследованы в условиях анализа реальных образиов. В обзоре обсуждаются достоинства и недостатки разработанных биосенсоров. Рассматривается возможность их практического использования. 
Ключевые слова: электрохимический биосенсор, иммобилизованный фермент, субстрат, ингибитор, мультибиосенсор.

\section{REFERENCES}

1. Turner A. P. Biosensors: sense and sensibility // Chem. Soc. Rev.-2013.-42, N 8.-P. 3184-3196.

2. Dzyadevych S. V., Soldatkin A. P., Korpan Y. I. et al. Biosensors based on enzyme field-effect transistors for determination of some substrates and inhibitors // Anal. Bioanal. Chem.-2003.-377, N 3.-P. 496-506

3. Dzyadevych S. V., Arkhypova V. N., Soldatkin A. P. et al. Conductometric enzyme biosensors // Handbook of Biosensors and Biochips / Eds S. Marcs, D. C. Cullen, I. Karube et al.-Chichester: J. Willey \& Sons Ltd., 2007.-P. 379-393.

4. Dzyadevych S. V., Arkhypova V. N., Soldatkin A. P. et al. Amperometric enzyme bio- sensors: past, present and future // ITBMRBM.-2008.-29, N 2.- P. 171-180.

5. Dzyadevych S. V., Soldatkin A. P., El'skaya A. V. et al. Enzyme biosensors based on ion-selective field-effect transistors // Anal. Chim. Acta.-2006.-568, N 1-2.-P. 248-258.

6. Shul'ga A. A., Sandrovsky A. K., Strikha V. I. et al. Overall characterization of ISFET-based glucose biosensor // Sens. Actuators B: Chem.-1992.-10, N 1.-P. 41-46.

7. Dzyadevich S. V., Korpan Y. I., Arkhipova V. N. et al. Application of enzyme field-effect transistors for determination of glucose concentrations in blood serum // Biosens. Bioelectron.1999.-14, N 3.-P. 283-287.

8. Boubryak O. A., Soldatkin A. P., Starodub N. F. et al. Determination of urea in blood serum by a urease biosensor based on an ion-sensitive field-effect transistor // Sens. Actuators B: Chem.1995.-27, N 1-3.-P. 429-431.

9. Hendji A. N., Jaffrezic-Renault N., Martelet C. et al. Sensitive detection of pestecides using differential ISFET-based scheme and immobilized cholinesterases // Anal. Chim. Acta.-1993.-281, N 1.-P. 3-11.

10. Arkhypova V. N., Dzyadevych S. V., Soldatkin A. P. et al. Multibiosensor based on enzyme inhibition analysis for determination of different toxic substances // Talanta.-2001.-55, N 5.P. 919-927.

11. Gorchkov D. V., Soldatkin A. P., Maupas H. et al. Correlation between the electrical charge propertes of polymeric membranes and the characteristics of ion selective field effect transistors or penicillinase based enzymatic field ef- fect transistors // Anal. Chim. Acta.-1996.-331, N 3.-P. 217-223.

12. Korpan Y. I., Gonchar M. V., Sibirny A. A. et al. Development of highly selective and stable potentiometric sensors for formaldehyde determination // Biosens. Bioelectron.-2000.-15, N 1-2.P. 77-83

13. Soldatkin A. P., Montoriol J., Sant W. et al. Creatinine sensitive biosensor based on ISFETs and creatinine deiminase immobilised in BSA membrane // Talanta.-2002.-58, N 2.-P. 351-357.

14. Soldatkin A. P., Montoriol J., Sant W. et al. Development of potentiometric creatinine-sensitive biosensor based on ISFET and creatinine deiminase immobilised in $\mathrm{PVA} / \mathrm{SbQ}$ photopolymeric membrane // Mater. Sci. Eng. C.-2002.-21, N 1-2.-P. 75-79.

15. Anh T. M., Dzyadevych S. V., Soldatkin A. P. et al. Development of tyrosinase biosensor based on $\mathrm{pH}$-sensitive field-rffect transistor for phenols determination in water solution // Talanta.2002.-56, N 4.- P. 627-634.
16. Dzyadevych S. V., Mai Anh T., Soldatkin A. P. et al. Development of enzyme biosensor based on $\mathrm{pH}$-sensitive field-effect transistors for detection of phenolic compounds // Bioelectrochemistry.-2002.-55, N 1-2.-P. 79-81.

17. Biloivan O. A., Dzyadevich S. V., El'skaya A. V. et al. Development of bi-enzyme microbiosensor based on solid-contact ionselective microelectrodes for protein detection // Sens. Actuators B: Chem.-2007.-123, N 2.-P. 1096-1100.

18. Marrakchi M., Dzyadevych S. V., Biloivan O. A. et al. Development of trypsine biosensor based on ion-sensitive field-effect transistors for proteins deter mination // Mater. Sci. Eng. C.-2006.-26, N 2-3.-P. 369-373.

19. Biloivan O. A., Dzyadevich S. V., Boubriak O. A. et al. Development of enzyme biosensor based on ISFETs for Quantitative analysis of serine proteinases // Electroanalysis.-2004.-16, N 22.P. 1883-1889.

20. Soldatkin A. P., El'skaya A. V., Shul'ga A. A. et al. Glucose sensitive field-effect transistor with additional Nafion membrane: reduction of influence of buffer capacity on the sensor response and extention of its dynamic range // Anal. Chim. Acta.-1993.283, N 3.-P. 695-701.

21. Volotovsky V., Soldatkin A. P., Shulga A. A. et al. Glucose-sensitive ion-sensitive field-effect transistor-based biosensor with additional positively charged membrane. Dynamic range extension and reduction of buffer concentration influence on the sensor response // Anal. Chim. Acta.-1996.-322, N 1-2.P. 77-81.

22. Gorchkov D. V., Soldatkin A. P., Poyard S. et al. Application of charged polymeric materials as additional permselective membranes for improvement of the performance characteristics of ureasensitive enzymatic field effect transistors. 1. Determination of urea in model solutions // Mater. Sci. Eng. C.-1997.-5, N 1.P. 23-28.

23. Gorchkov D. V., Soldatkin A. P., Poyard S. et al. Application of charged polymeric materials as additional permselective membranes for improvement of the performance characteristics of ureasensitive enzymatic field effect transistors. 2. Urea determination in blood serum // Mater. Sci. Eng. C.-1997.-5, N 1.-P. 29-34.

24. Soldatkin A. P., Dzyadevych S. V., El'skaya A. V. et al. Pathways for improving potentiometric and conductometric enzymatic biosensors // Encyclopedia of Sensors / Eds C. A. Grimes, E. C. Dickey, M. V. Pishko.-Stevenson Ranch: Amer. Sci. Publ., 2006.Vol. 7.-P. 331-348.

25. de Melo J. V., Soldatkin A. P., Martelet C. et al. Use of competitive inhibition for driving sensitivity and dynamic range of urea ENFETs // Biosens. Bioelectron.-2003.-18, N 4.-P. 345-351.

26. Soldatkin A. P., Montoriol J., Sant W. et al. A novel urea sensitive biosensor with extended dynamic range based on recombinant urease and ISFETs // Biosens. Bioelectron.-2003.-19, N 2.P. 131-135.

27. Zinchenko O. A., Marchenko S. V., Sergeyeva T. A. et al. Application of creatinine-sensitive biosensor for hemodialysis control // Biosens. Bioelectron.-2012.-35, N 1.-P. 466-469.

28. Marchenko S. V., Soldatkin A. P. Potentiometric biosensor based on recombinant urease for urea detection in real biological samples // Sensor Electronics and Microsystem Technologies.2012.-3 (9), N 4.-P. 40-48.

29. Soldatkin A. P. Urease-based biosensor with improved sensitivity for analysis of heavy metal ions // Biopolym. Cell.-1997.-13, N 5.-P. 377-379.

30. Dzyadevych S. V., Arkhypova V. N., Martelet C. et al. Potentiometric biosensors based on ISFETs and immobilized cholinesterases // Electroanalysis.-2004.-16, N 22.-P. 1873-1882. 
31. Dzyadevych S. V., Soldatkin A. P., Arkhypova V. N. et al. Earlywarning electrochemical biosensor system for the environmental monitoring based on enzyme inhibition effect // Sens. Actuators B: Chem.-2005.-105, N 14.-P. 81-87.

32. Arkhypova V. N., Dzyadevych S. V., Soldatkin A. P. et al. Development and optimisation of biosensors based on $\mathrm{pH}$-sensitive field effect transistor and cholinesterase for sensitive detection of solanaceous glycoalkaloids // Biosens. Bioelectron.-2003.18, N 8.-P. 1047- 1053.

33. Arkhypova V. N., Dzyadevych S. V., Soldatkin A. P. et al. Application of enzyme field effect transistors for fast detection of total glycoalkaloids content in potatoes // Sens. Actuators B: Chem.2004.-103, N 1-2.-P. 416-422.

34. Soldatkin A. P., Arkhypova V. N., Dzyadevych S. V. et al. Analysis of the potato glycoalkaloids by using of enzyme biosensor based on pH-ISFETs // Talanta.-2005.-66, N 1.-P. 28-33.

35. Dzyadevych S. V., Arkhypova V. N., Soldatkin A. P. et al. Enzyme biosensor for tomatine detection in tomatoes // Anal. Lett.2004.-37, N 8.- P. 1611-1624.

36. Volotovsky V., Kim N. EDTA Determination by urease-based inhibition biosensor // Electroanalysis.-1997.-10, N 1.-P. 61-63.

37. Korpan Y. I., Nazarenko E. A., Skryshevskaya I. V. et al. Potato glycoalkaloids: true safety or false sense of security? // Trends Biotechnol.-2004.-22, N 3.-P. 147-151.

38. Nazarenko A. A., Soldatkin O. P., Sosovska O. F. et al. Potentiometric biosensors for determination of potato glycoalkaloids: control of its analytical characteristics, comparison with thin-layer chromatography method // Biopolym. Cell.-2005.-21, N 3.-P. 275-282.

39. Arkhypova V. N., Dzyadevych S. V., Jaffrezic-Renault N. et al. Biosensors for assay of glycoalkaloids in potato tubers // Prik1. Biokhim. Mikrobiol.-2008.-44, N 3.-P. 347-352.

40. Soldatkin O. O., Nazarenko O. A., Pavlyuchenko O. S. et al. Optimization of enzymatic bioselective elements as components of potentiometric multibiosensor // Biopolym. Cell.-2008.-24, N 1.-P. 41-50.

41. Soldatkin O. O., Pavlyuchenko O. S., Kukla O. L. et al. Optimization of multibiosensor operation for inhibitory analysis of toxins // Biopolym. Cell.-2008.-24, N 6.-P. 494-502.

42. Soldatkin O. O., Pavlyuchenko O. S., Kukla O. L., Dzyadevych S. $V$. Development of procedure of multibiosensor detection of heavy metals and pesticides in environment // Biotechnology.2010.-3, N 2.-P. 71-81.

43. Soldatkin O. O., Pavlyuchenko O. S., Kukla O. L. et al. Application of enzyme multibiosensor for toxicity analysis of real water samples of different origin // Biopolym. Cell.-2009.-25, N 3.-P. 204-209.

44. Soldatkin A. P., Dzyadevych S. V., Korpan Y. I. et al. Biosensors based on conductometric detection // Biopolym. Cell.-1998.14, N 4.-P. 268-276.

45. Shul'ga A. A., Soldatkin A. P., El'skaya A. V. et al. Thin-film conductometric biosensors for glucose and urea determination // Biosens. Bioelectron.-1994.-9, N 3.-P. 217-223.

46. Dzyadevich S. V., Shul'ga A. A., Soldatkin A. P. et al. Conductometric biosensor based on cholinesterases for sensitive detection of pesticides // Electroanalysis.-1994.-6, N 9.-P. 752-758.

47. Korpan Y. I., Dzyadevich S. V., Arkhipova V. N. et al. Enzymebased electrochemical sensors for formaldehyde detection // Sens. Mater.-2000.-12, N 2.-P. 79-86.

48. Dzyadevych S. V., Arkhypova V. N., Korpan Y. I. et al. Conductometric formaldehyde sensitive biosensor with specifically adapted analytical characteristics // Anal. Chim. Acta.-2001.445, N 1.- P. 47-55.
49. Saiapina O. Y., Dzyadevych S. V., Jaffrezic-Renault N., Soldatkin $O$. P. Development and optimization of a novel conductometric bi-enzyme biosensor for L-arginine determination // Talanta.2012.-92.-P. 58-64.

50. Zhylyak G. A., Dzyadevich S. V., Korpan Y. I. et al. Application of urease conductometric biosensor for heavy-metal ion determination // Sens. Actuators B: Chem.-1995.-24, N 1-3.-P. 145-148.

51. Jaffrezic-Renault N., Dzyadevych S. V. Conductometric microbiosensors for environmental monitoring // Sensors.-2008.-8, N 4.P. 2569-2588.

52. Mai Anh T., Dzyadevych S. V., Prieur N. et al. Detection of toxic compounds in real water samples using a conductometric tyrosinase biosensor // Mater. Sci. Eng. C.-2006.-26, N 2-3.-P. 453-456.

53. Soldatkin A. P., El'skaya A. V., Shul'ga A. A. et al. Glucose sensitive conductometric biosensor with additional Nafion membrane: reduction of influence of buffer capacity on the sensor response and extension of its dynamic range // Anal. Chim. Acta.1994.-288, N 3.-P. 197-203.

54. Dzyadevych S. V., Soldatkin A. P., Chovelon J. M. Assessment of the toxicity of parathion and its photodegradation products in water samples using conductometric enzyme biosensors // Anal. Chim. Acta.-2002.-459, N 1.-P. 33-41.

55. Dzyadevych S. V., Chovelon J. M. A comparative photodegradation studies of methyl parathion by using Lumistox test and conductometric biosensor technique // Mater. Sci. Eng. C.-2002.21, N 1-2.-P. 55-60.

56. Soldatkin O. O., Peshkova V. M., Dzyadevych S. V. et al. Novel sucrose three-enzyme conductometric biosensor // Mater. Sci. Eng. C.-2008.- 28.-P. 959-964.

57. Peshkova V. M., Saiapina O. Y., Soldatkin O. O. et al. Conductometric enzyme biosensor for lactose detection // Biotechnology.-2008. -1, N 4.-P. 76-84.

58. Peshkova V. M., Saiapina O. Y., Soldatkin O. O., Dzyadevych S. $V$. Enzyme conductometric biosensor for maltose determination // Biopolym. Cell.-2009.-25, N 4.-P. 272-278.

59. Korpan Y. I., Dzyadevich S. V., Zharova V. P., El'skaya A. V. Conductometric biosensor for ethanol detection based on whole yeast cells // Ukr. Biokhim. Zh.-1994.-66, N 1.-P. 78-82.

60. Chouteau C., Dzyadevych S. V., Chovelon J. M., Durrieu C. Development of novel conductometric biosensors based on immobilised whole cell Chlorella vulgaris microalgae // Biosens. Bioelectron.-2004.-19, N 9.-P. 1089-1096.

61. Chouteau C., Dzyadevych S. V., Durrieu C., Chovelon J. M. A bi-enzymatic whole cell conductometric biosensor for heavy metal ions and pesticides detection in water samples // Biosens. Bioelectron.-2005.-21, N 2.-P. 273-281.

62. Ben Ali M., Gonchar M., Gayda G. et al. Formaldehyde-sensitive sensor based on recombinant formaldehyde dehydrogenase using capacitance versus voltage measurements // Biosens. Biolectron.-2007.-22, N 12.-P. 2790-2795.

63. Goriushkina T. B., Soldatkin A. P., Dzyadevych S. V. Application of amperometric biosensors for analysis of ethanol, glucose, and lactate in wine // J. Agric. Chem.-2009.-57, N 15.-P. 6528-6535.

64. Goriushkina T. B., Soldatkin A. P., Dzyadevych S. V. Application of amperometric enzyme biosensors for wine and must analysis // Procedia Chem.-2009.-1, N 1.-P. 277-280.

65. Shkotova L. V., Goryushkina T. B., Tran-Minh C. et al. Amperometric biosensor for lactate analysis in wine and must during fermentation // Mater. Sci. Eng. C.-2008.-28, N 5-6.-P. 943-948.

66. Shkotova L. V., Soldatkin A. P., Gonchar M. V. et al. Amperometric biosensor for ethanol detection based on alcohol oxidase immobilised within electrochemically deposited Resydrol film // Mater. Sci. Eng. C.-2006.-26, N 2-3.- P. 411-414. 
67. Goriushkina T. B., Shkotova L. V., Gayda G. Z. et al. Amperometric biosensor based on glycerol oxidase for glycerol determination // Sens. Actutors B: Chem.-2010,-144, N 2.-P. 361-367.

68. Schuvailo O. M., Soldatkin O. O., Lefebvre A. et al. Highly selec- tive microbiosensors for in vivo measurements of glucose, lactate and glutamate // Anal. Chim. Acta.-2006.-573-574.P. 110-116.

69. Schuvailo O. N., Dzyadevych S. V., El'skaya A. V. et al. Carbonfibre-based microbiosensors for in vivo measurements of acetylcholine and choline // Biosens. Bioelectron.-2005.-21, N 1.P. 87-94.

70. Schuvailo O. M., Gaspar S., Soldatkin A. P., Csoregi E. Ultramicrobiosensor for the selective detection of glutamate // Electroanalysis.-2007.-19, N 1.-P. 71-78.

71. Pernot P., Mothet J. P., Schuvailo O. et al. Characterization of a yeast D-amino acid oxidase microbiosensor for D-serine detection in the central nervous system // Anal. Chem.- 2008.-80, N 5.-P. 1589-1597.

72. Soldatkin O. O., Schuvailo O. M., Marinesco S. et al. Microbiosensor based on glucose oxidase and hexokinase co-immobilised on platinum microelectrode for selective ATP detection // Talanta.-2009.-78, N 3.-P. 1023-1028.

73. Tavolaro A., Tavolaro P., Drioli E. Zeolite inorganic supports for BSA immobilization: comparative study of several zeolite crystals and composite membranes // Colloids Surf. B: Biointerfaces.-2007-55, N 1.-P. 67-76.

74. Kirdeciler S. K., Soy E., Ozturk S. et al. A novel urea conductometric biosensor based on zeolite immobilized urease // Talanta.-2011.-85, N 3.-P. 1435-1441.

75. Soldatkin O. O., Soy E., Errachid A. et al. Influence of composition of zeolite/enzyme nanobiocomposites on analytical characteristics of urea biosensor based on ion-selective field-effect transistors // Sens. Lett.-2011.-9, N 6.-P. 2320-2326.

76. Soldatkin O. O., Kucherenko I. S., Shelyakina M. et al. Application of different zeolite for improvement of the characteristics of a $\mathrm{pH}$-FET biosensor based on immobilized urease // Electroanalysis.-2013.-25, N 2.-P. 468-474.

77. Saiapina O. Y., Dzyadevych S. V., Walcarius A., Jaffrezic N. A novel highly sensitive zeolite-based conductometric microsensor for ammonium determination // Anal. Lett.-2012.-45, N 11.P. 1467-1484.

78. Saiapina O. Y., Pyeshkova V. M., Soldatkin O. O. et al. Conductometric enzyme biosensors based on natural zeolite clinoptilolite for urea determination // Mater. Sci. Eng. C.-2011.-31, N 7.P. 1490-1497.

79. Saiapina O. Y., Matsyshyn M., Pyeshkova V. M. et al. Application of ammonium-selective zeolite for enhancement of conductometric bi-enzyme biosensor for L-arginine detection // Sensor Electronics and Microsystem Technologies.-2012.-3 (9), N 4.-P. 49-66.

80. Kucherenko I. S., Soldatkin O. O., Kasap B. O. et al. Elaboration of urease adsorption on silicalite for biosensor creation // Electroanalysis.-2012.-24, N 6.-P. 1380-1385.
81. Biloivan O. A., Rogaleva N. S., Korpan Y. I. Optimization of bioselective membrane of amperometric enzyme sensor on basis of glucose oxidase using $\mathrm{NH}_{2}$-modified multi-walled carbon nanotubes // Biopolym. Cell.-2010.-26, N 1.-P. 56-61.

82. Rogaleva $N$., Korpan Y., Biloivan $O$. Glucose biosensor based on screen-printed electrodes and glucose oxidase layer modified by MWCNT-NH $\mathrm{N}_{2} / /$ Sens. Lett.-2011.-9, N 6.-P. 2356-2359.

83. Wulff $G$. Molecular imprinting in cross-linked materials with the aid of molecular templates - a way towards artificial antibodies // Angew. Chem. Int. Ed. Engl.-1995.-34, N 17.-P. 1812-1832.

84. Sergeyeva T. A., Piletsky S. A., Brovko A. A. et al. Conductimetric sensor for atrazine detection based on molecularly imprinted polymer membranes // Analyst.-1999.-124.-P. 331-334.

85. Sergeyeva T. A., Piletsky S. A., Brovko A. A. et al. Selective recognition of atrazine by molecularly imprinted polymer membranes. Development of conductometric sensor for herbicides detection // Anal. Chim. Acta.-1999.-392, N 2-3.-P. 105-111.

86. Sergeyeva T. A., Matuschewski H., Piletsky S. A. et al. Molecularly imprinted polymer membranes for substance-selective solidphase extraction from water by surface photo-grafting polymerization // J. Chromatogr. A.-2001.-907, N 1-2.-P. 89-99.

87. Matuschewski H., Sergeyeva T. A., Bendig J. et al. Surface engineering: Molecularly imprinted affinity membranes by photograft polymerization // SPIE.-2001.-4205.-P. 65-74.

88. Sergeyeva T. A., Piletsky S. A., Piletskaya E. V. et al. In situ formation of porous molecularly imprinted polymer membranes // Macromolecules.-2003.-36, N 19.-P. 7352-7357.

89. Sergeyeva T. A., Panasyuk-Delaney T. L., Piletska O. V. et al. Capacitive sensor for environmental monitoring based on thin films of molecularly imprinted polymers. Computational modeling for optimization of composition of synthetic mimics of bioreceptors // Ukr. Biokhim. Zh.-2006.-78, N 2.-P. 121-130.

90. Piletsky S. A., Piletskaya E. V., Sergeyeva T. A. et al. Molecularly imprinted self-assembled films with specificity to cholesterol // Sensors and Actuators B: Chem.-1999.-60, N 2-3.-P. 216-220.

91. Sergeyeva T. A., Slinchenko O. A., Gorbach L. A. et al. Catalytic molecularly imprinted polymer membranes: development of the biomimetic sensor for phenols detection // Anal. Chim. Acta.2010.-659, N 1-2.-P. 274-279.

92. Sergeyeva T. A., Piletska O. V., Goncharova L. A. et al. Sensor system based on molecularly-imprinted polymer membranes for the selective recognition of aflatoxin b1 // Ukr. Biokhim. Zh.2008.-80, N 3.-P. 84-93.

93. Sergeyeva T. A., Gorbach L. A., Slinchenko O. A. et al. Towards development of colorimetric test-systems for phenols detection based on computationally-designed molecularly imprinted polymer membranes // Mater. Sci. Eng. C.-2010.-30, N 3.-P. 431-436.

94. Sergeyeva T. A., Gorbach L. A., Piletska E. V. et al. Colorimetric test-systems for creatinine detection based on composite molecularly imprinted polymer membranes // Anal. Chim. Acta.2013.-770.-P. 161-168. 